\title{
Energy potentials and sustainability-the case of sisal residues in Tanzania
}

Originally published as:

Julia Terrapon-Pfaff, Manfred Fischedick, Heiner Monheim (2012):

Energy potentials and sustainability-the case of sisal residues in Tanzania In: Energy for Sustainable Development, Volume 16, Issue 3, September 2012, Pages 312-319 
Julia Terrapon-Pfaff ${ }^{\text {a,b }}{ }^{*}$, Manfred Fischedick ${ }^{\text {a }}$, Heiner Monheim ${ }^{b}$

\section{Energy potentials and sustainability-the case of sisal residues in Tanzania}

a Wuppertal Institute for Climate, Environment and Energy, Postfach 10 04 80,42004 Wuppertal, Germany

b University of Trier, Department of Applied Geography, 54286 Trier, Germany

* Corresponding author: Julia Terrapon-Pfaff, Postfach 1004 80, D-42004 Wuppertal, Germany E-mail: julia.pfaff@wupperinst.org

Phone: n/a

Fax: $\mathrm{n} / \mathrm{a}$ 


\begin{abstract}
The energy potential of agricultural residues in Tanzania has so far not been evaluated and quantified sufficiently. Moreover, the scientific basis for estimations of the sustainable potential of wastes and residues is still very limited. This paper presents an attempt to evaluate the theoretical and technical potential of residues from the sisal sector in Tanzania with regards to energy recovery through anaerobic digestion. The characteristics and availability of sisal residues are defined and a set of sustainability indicators with particular focus on environmental and socio-economic criteria is applied. Our analysis shows that electricity generation with sisal residues can be sustainable and have positive effects on the sustainability of sisal production itself. All sisal residues combined have an annual maximum electricity potential of 102 Gigawatt hours (GWh) in 2009, corresponding to up to 18.6 Megawatt (MW) of potential electric capacity installations. This estimated maximum potential is equivalent to about $3 \%$ of the country's current power production. Utilizing these residues could contribute to meeting the growing electricity demand and offers an opportunity for decentralized electricity production in Tanzania.
\end{abstract}

Keywords: agricultural residues, sisal, anaerobic digestion, electricity, heat, sustainability, Tanzania

\title{
1. Introduction
}

In Tanzania, traditional biomass fuels are the dominating energy source, accounting for over $90 \%$ of the total energy consumption. Commercial energy sources account for $10 \%$ of consumption, of which electricity accounts for only $2 \%$. Accordingly, the levels of electricity consumption per capita are among the lowest worldwide. These numbers reflect not only insufficient availability but also lack of access to modern energy services. To date, only $14 \%$ of the population has access to electricity (MEM, 2010). The electricity access rate in rural areas is at $2 \%$ significantly lower compared to urban areas, where $39 \%$ of the population has access to electricity (IEA, 2008). With an intended increase of electricity access combined with continuing growth in the commercial, industrial, agricultural and residential sector, the Ministry of Energy and Minerals projects that the electricity demand in Tanzania will triple by 2020 (MEM, 2010). Moreover, the present demand for electricity already exceeds the installed generation capacity of 1,219 MW, of which $561 \mathrm{MW}$ is hydro-based and $658 \mathrm{MW}$ is thermal-based (diesel and natural gas) (MEM, 2010). Although the situation has improved after the country suffered its worst power shortage in 2006/2007, due to falling water levels in the hydroelectric dams caused by enduring droughts, blackouts still occur on a daily basis. New power rationings were announced in 2010 after the breakdown of four power generators. These shortcomings in the power sector not only affect households but also threaten Tanzania's long-term economic growth and competitiveness. Companies have either to rely on expensive backup systems like diesel generators or to completely suspend their business activities during load shedding. The World Bank (2010) estimates that the average cost of power shortages in Africa is equivalent to $2.1 \%$ of the gross domestic product (GDP). Therefore, the question of how to stabilize, secure and increase the power supply is critical for Tanzania's economic and social development.

Renewable energy sources are expected to play an important role in addressing these problems. In rural areas, where grid extension is not feasible, renewable energies are regarded as a particularly promising option for decentralized electricity generation. With regard to the region's high potential for producing biomass, one of the promoted strategies is the use of modern bioenergy technologies (MEM, 2010). However, it is known that the use of biomass for energy applications can lead to land use competition, environmental degradation and put food security at risk. Bioenergy strategies must therefore be carefully chosen. Pathways that use biogenic wastes and agricultural residues entail far fewer risks of resource competition compared to those using food and energy crops to generate energy. But so far residues represent a still largely untapped energy potential worldwide (UNEP, 2009). Accordingly, the energy potential of residues and wastes in Tanzania is not well documented. Nevertheless, agricultural residues from cash- and food crop production have a high theoretical potential as feedstock for electricity conversion in an agriculture-dependent developing country like Tanzania. ${ }^{1}$

The Tanzanian economy depends heavily on agriculture, which accounts for approximately $25 \%$ of GDP, provides $85 \%$ of exports, and employs $80 \%$ of the workforce (FAO, 2010). The sector itself is dominated by

\footnotetext{
${ }^{1}$ Agricultural residues also include animal manure, but this feedstock is not included in this paper. In Tanzania traditional smallscale farmers dominate the structure of keeping livestock. Approximately $99 \%$ of the livestock belongs to these traditional farmers, while commercial ranches and dairy farms constitute the remaining $1 \%$ (FAO \& Livestock information, sector analysis and policy branch [AGAL], 2005). Most small-scale farmers keep their livestock free-range, which leaves the utilization of animal manure as feedstock a challenging task. Providing sufficient streams of preferably wet dung is in many cases neither practical nor feasible.
} 
subsistence farming and rain-fed crop production. Only one-fifth of agricultural production can be categorized as commercial. But considerable amounts of agricultural residues are mainly produced in regions with private estates and intensive commercial smallholders farming (GTZ, 2005). Consequently most concentrated amounts of agricultural residues are accumulated in the agro-industrial crop production. Therefore, the starting point of a holistic approach to use agriculture residues for electricity generation should be the utilization of residues from commercial crop production.

Tanzania's major sources for agricultural residues are coffee, rice, sisal, sugar, cashew nut, maize, coconut, cotton and banana. Although these crops produce different types of residues, all crop residues can, for convenience, be divided into two main categories: field residues remaining on the fields after harvesting, and process residues resulting from crop processing. Process residues are particularly promising due to their large and localized availability, thus limiting the need for additional logistic structures. The utilization of most crop residues is still very limited in Tanzania, although wood fuel scarcity has lead to an increasing amount of residues directly used as cooking fuel. Traditionally, most of the agricultural crop residues are burnt or left in the fields or on the farms to facilitate the harvesting process, as pest control measures or simply because there is no other possibility to dispose them.

Considerable amounts of agricultural crop residues for cogeneration of electricity have so far only been used in the sugar sector. But the situation is slowly changing and the first biogas plant, which uses only sisal wastes as substrate to generate electricity, started operating in Hale, Tanzania in 2008. The plant is running successfully for two years now, proving that sisal residues are a good quality substrate for anaerobic digestion. Plans are already in place to scale-up cogeneration of electricity from sisal wastes, demonstrating the growing interest in this specific energy source. Hence, the present study focuses on the estimation of the sisal residue potential for small-scale decentralized electricity generation and the associated environmental and socioeconomic risks and opportunities.

\section{Research Objectives}

Several studies have highlighted the potential for bioenergy production on the African continent (Dasappa, S., 2010; Smeets et al., 2007; Smeets et al. 2004; Marrison \& Larson, 1996). But more detailed country level and crop specific assessments are necessary to understand the practical prospects for future biomass energy production in Africa. The focus of this paper is to assess the theoretical and technical potential of cogenerating electricity and heat with agricultural crop residues in Tanzania's sisal sector, with the following detailed objectives: (i) to estimate the theoretical available amount of sisal residues based on both aggregated and sitespecific data; (ii) to evaluate the availability and technical realizable energy potential of sisal residues; (iii) to assess ecological and socio-economic effects of using these residues for energy generation.

\section{Methods}

The following quantitative and qualitative methods were adopted to estimate the amount and energetic values of sisal residues theoretically available, and to assess how selected sustainability aspects would be influenced by the use of these residues.

(i) The amount of agricultural residues produced is estimated using the residue-to-product ratio (RPR). The necessary crop production data were derived from the Tanzania Sisal Board [TSB], the National Bureau of Statistics and FAOSTAT.

(ii) Structured interviews and consultations with key government and private sector stakeholders were conducted to gather qualitative information on projects, context, implementation, results and impacts. Furthermore, the predominant attitude regarding the use of agricultural residues for energy generation in the country was assessed through attendance of various stakeholder workshops.

(iii) A detailed study of available literature and scientific reports on the production, collection, disposal and other uses of residues was carried out to collect additional data and information.

\subsection{Estimating the amount of crop residues}

The type and amount of agricultural residues available varies from crop to crop depending on the plant structure, seasonal availability, harvesting methods, irrigation practices, soil quality and other factors. But the amount of residues produced is directly related to the corresponding crop production. So if the crop production quantities at a particular time are known, it is possible to estimate the amounts of agricultural residues produced using the residue-to-product ratio (RPR) (Koopmans \& Koppejan, 1998). This method has been widely applied to estimate the potential availability of agricultural residues for energy generation (Rosillo-Calle, 2007). Although this approach has its limitations as it does not include future developments 
and investments in the agricultural sector, it is suitable to estimate the current country-specific energy potential of residues. The general equation for estimating the agricultural residual biomass is as follows:

$$
R=C_{p} * R P R
$$

where $(R)$ is the total available agricultural residual biomass in tonnes per year, $\left(C_{p}\right)$ the amount of crop production in tonnes per year and (RPR) the residue-to-product ratio in tonnes of residues per tonnes of product. While the RPR values for sugarcane are well known, the RPR for sisal residues must be estimated. Using the following equation the RPR can be predicted if the quantity of residues is known. Instead of production figures, data of the cultivated area and the average agricultural yields are used:

$$
R P R=R / Y
$$

where (RPR) is the residue-to-product ratio in tonnes of residues per tonnes of product, (R) the average available agricultural residual biomass in tonnes per hectare per year, and $(\mathrm{Y})$ the yield of product in tonnes per hectare per year.

\subsection{Estimating the energy potential}

The production of electricity and heat through anaerobic digestion depends on the gas formation potential of the substrates used. The potential volumes of biogas and methane can be calculated if following factors are known: amount of residue per period of time, dry matter content of the residue, organic dry matter content, biogas potential and specific yield of methane for the substrate (Kaltschmitt et al., 2008). In the next step the heat and electricity output and the necessary capacity can be estimated from the potential amount of methane and the expected efficiency of the power plant. The conversion factors (see Table 1) used to calculate the technical biogas potential from sisal residues were assumed to be similar to those for Kenya (GTZ, 2010).

Table 1: Conversion factors and full load hours used for the calculation of biogas potentials

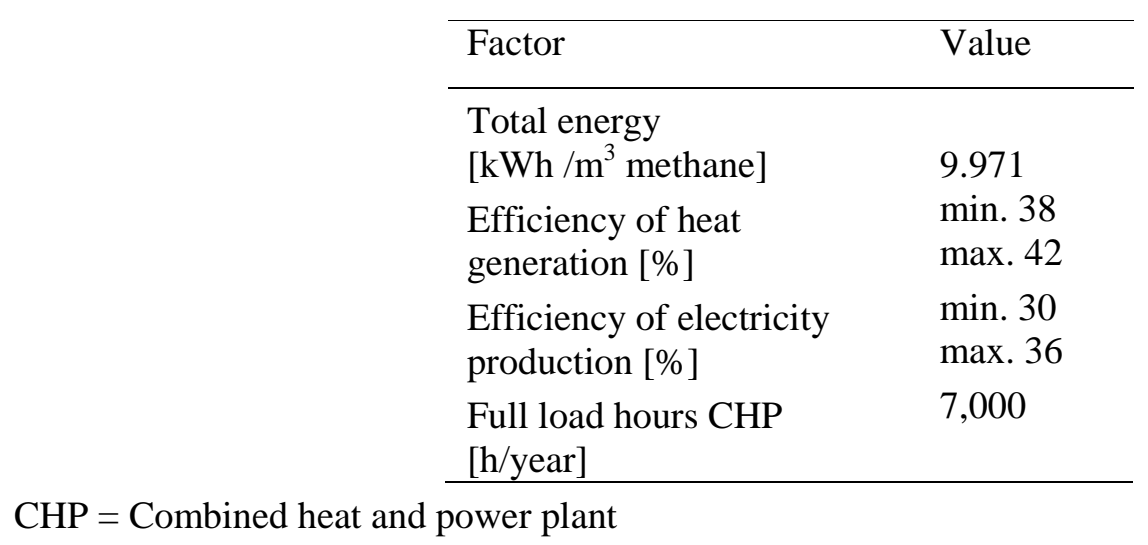

\subsection{Assessing environmental and socio-economic risks and opportunities}

Besides determining the available biophysical potential of sisal residues for electricity generation, further aspects need to be considered. In particular, environmental and socio-economic factors define how and where the potential can be utilized in a sustainable manner ${ }^{2}$. The evaluation of environmental and socio-economic risks and opportunities is based on a selection of sustainability criteria developed by the Roundtable on Sustainable Biofuels [RSB]. Altogether, the RSB defines twelve principles that focus on social and environmental sustainability (RSB, 2010). The following six principles have been identified as primary for the sisal sector and applied in this study: water use and quality, biodiversity, soil health, greenhouse gas (GHG) emissions, food security and social and rural development.

An important aspect of environmental sustainability in the case of sisal is the avoidance of methane emissions from the disposal of sisal pulp and wastewater at solid waste disposal sites. The calculation method proposed by the Intergovernmental Panel on Climate Change (IPCC) based on a first order decay model

\footnotetext{
${ }^{2}$ There is no universally accepted definition of sustainability. In this paper the focus areas are socio-economic and environmental sustainability. Economic aspects require further research and will not be considered here, because the economics of biofuels depend on multiple site specific and outside factors and because biofuels are part of two of the most controlled and subsidized markets in the world (agriculture and energy),
} 
adopted by the Clean Development Mechanism of the United Nations Framework Convention on Climate Change (UNFCCC) is used here to quantify the avoidance of methane emissions (UNFCCC, 2010). The model differentiates between different types of waste with respectively different decay rates and different fractions of degradable organic carbon. The parameters used for sisal disposal are based on Salum (2008).

\section{Results}

The quantification of the theoretical potential of sisal residues for energy generation is derived from the physical supply of biomass sources and represents the theoretical upper limit of the available energy supply (WBGU, 2009). The portion of this theoretical potential that is realizable with the current technical possibilities is referred to as technical potential.

\subsection{Residue generation from sisal}

Tanzania is the third largest producer of sisal fibers after Brazil and China (FAO, 2009; TSB, 2009). The key cultivation areas are Tanga, Morogoro, Kilimanjaro, Arusha and Mara (Tanzania Agricultural Sample Census, 2003). Traditionally, the fiber is used to produce ropes, carpets and clothing, which are sold on the domestic and international markets.

Lately, sisal fibers have also been used in the automotive sector and for specialist paper manufacturing, which contributed to the worldwide increase in fiber demand during recent years. Likewise an upward trend in the fiber production in Tanzania has been observed from the late nineties until 2008. However, this development was reversed after 2008, when the sisal market and industry were negatively affected by the global economic downturn. The Tanzanian production dropped about one-third from 2008 to 2009 and the amount of residues generated decreased accordingly (Figure 1, based on data from TSB, 2010).

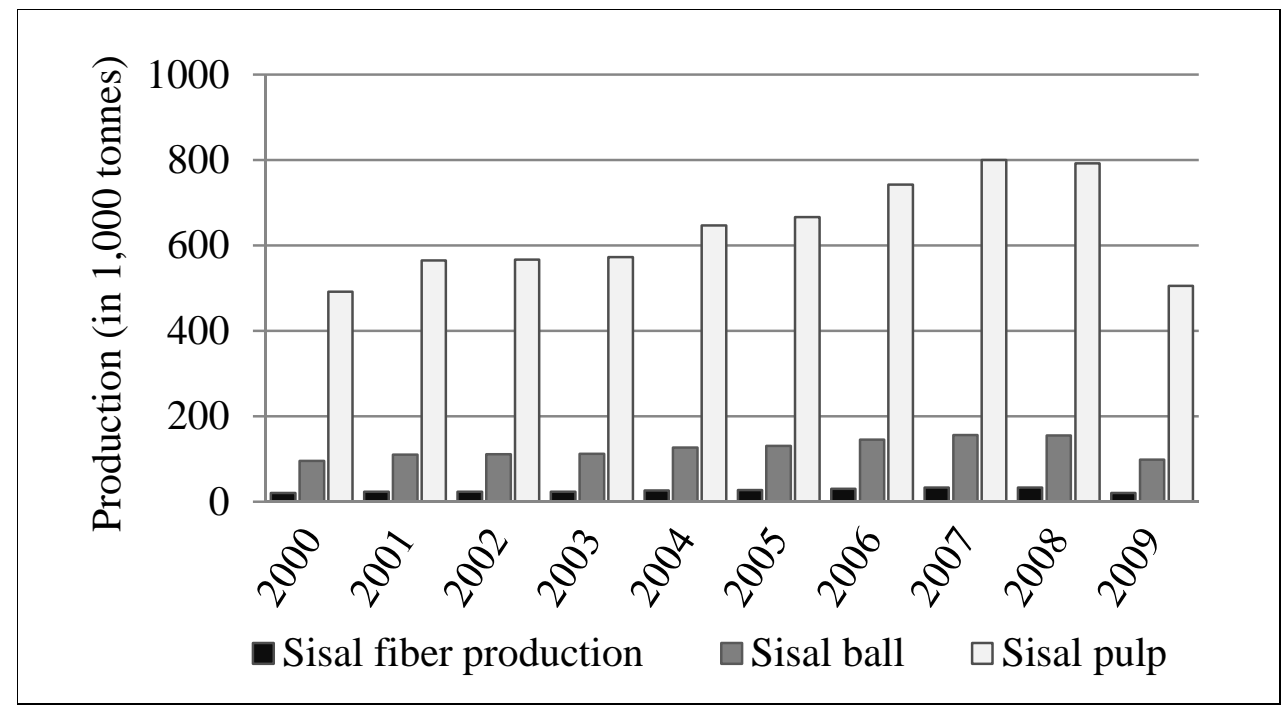

Figure 1: Sisal fiber and sisal residue production in tonnes in Tanzania from 2000 to 2009.

Two types of residues are available from the perennial sisal plant: the sisal pulp from the leaves and the trunk, which is also known as sisal ball. The product, i.e. sisal fiber, is extracted from the leaves, which can be harvested once or twice a year all year round depending on plant growth. In Tanzania the leaves are transported to a central processing site after harvesting. During the processing (decortication) large amounts of residues are generated, because the exploitable fibers make up only $4 \%$ of the total leaf weight. So that for each tonne of sisal fiber produced about 24 tonnes of leaf residues (sisal pulp) are generated (TSB, 2010). The residue-to-product ratio for the sisal pulp is therefore 24. Moreover, the process of extracting fiber from the leaves is very water intensive, so that additionally about $100 \mathrm{~m}^{3}$ of wastewater are generated per tonne of sisal fiber (GTZ, 2010). The sisal ball (old sisal plant) can be regarded as field residue. It is removed during replanting and provides further amounts of valuable biomass. For each hectare of sisal plantation, about seven tonnes of old plants are removed per year (assuming planting every ten years, 3,500 plants per hectare and a weight of $20 \mathrm{~kg}$ per sisal ball) (TSB, 2010; GTZ, 2010). With seven tonnes of sisal ball residues per hectare per year and an average production of 1.5 tonnes of sisal fiber per hectare per year in Tanzania (TSB, 2010), the RPR for the sisal ball is estimated to be 4.7. With a total sisal fiber production of 21,060 tonnes in 2009 
the following amount of residues can be calculated for Tanzania in 2009: 505,440 tonnes of sisal pulp, $2,106,000 \mathrm{~m}^{3}$ of wastewater and 98,982 tonnes of sisal ball from replanting.

\subsection{Energy potential of sisal residues}

Laboratory experiments (Muthangya et al., 2009; Mshandete et al., 2004; Kivaisi, 1996) and the first pilot plant demonstrated that sisal waste can be transformed into electricity by utilizing biogas through anaerobic digestion. The composition of sisal residues for anaerobic digestion is given in Table 2. The average dry matter (DM) content for sisal pulp is estimated to be $12 \%$, but the actual DM content measured in the pilot plant has so far only reached $6 \%$. This can be explained due to shifting composition of substrates depending on plant variety, habitat, climate, processing and many other factors (GTZ, 2010). It is essential to use both results, because data from the pilot plant reflects the local conditions in Tanzania, while average DM content stated in the literature (GTZ, 2010) shows what results can be reached under varying conditions.

Table 2: Characteristics of sisal residues

\begin{tabular}{|c|c|c|}
\hline & $\begin{array}{l}\text { sisal } \\
\text { pulp }\end{array}$ & sisal ball \\
\hline RPR & 24 & 4.7 \\
\hline DM content $[\% \mathrm{FM}]$ & $6-12$ & 29 \\
\hline oDM content $[\% \mathrm{DM}]$ & 85 & 93 \\
\hline Methane content [\%] & 60 & 60 \\
\hline $\begin{array}{l}\text { Methane potential }\left[\mathrm{m}^{3} / \mathrm{t}\right. \\
\mathrm{oDM}]\end{array}$ & 330 & 368 \\
\hline & \multicolumn{2}{|c|}{ wastewater } \\
\hline RPR & \multicolumn{2}{|l|}{100} \\
\hline COD degradability [\%] & \multicolumn{2}{|l|}{87} \\
\hline COD in waste water $[\mathrm{g} / \mathrm{l}]$ & \multicolumn{2}{|l|}{12} \\
\hline Methane content [\%] & \multicolumn{2}{|l|}{84} \\
\hline $\begin{array}{l}\text { Methane potential } \\
{\left[\mathrm{m}^{3} / \mathrm{t}_{\text {COD }} \text { removed }\right]}\end{array}$ & \multicolumn{2}{|l|}{400} \\
\hline
\end{tabular}

$\mathrm{FM}=$ fresh matter; $\mathrm{DM}=$ dry matter; $\mathrm{oDM}=$ organic dry matter; $\mathrm{COD}=$ chemical oxygen demand

Table 3: Energy potential of sisal residues per tonne of product

\begin{tabular}{lll}
\hline Residue type & Energy type & $\begin{array}{l}\text { Energy potential } \\
(\mathrm{kWh})\end{array}$ \\
\hline sisal pulp & electricity & $1,200-3,000$ \\
& heat & $1,500-3,500$ \\
sisal ball & electricity & 1,600 \\
& heat & 2,000 \\
wastewater & electricity & $1,200-1,500$ \\
$\left(100 \mathrm{~m}^{3}\right)$ & & \\
\hline
\end{tabular}

Taking these different parameters into account, the electricity and heat potentials per tonne of produced sisal fiber was calculated (Table 3). It is shown that all three residue types comprise noteworthy energy potentials. With regard to the available residue amount at the different processing sites the identified energy and heat potential is suitable for small scale decentralized power generation with generation capacities ranging from $150 \mathrm{~kW}$ up to $1 \mathrm{MW}$. The accumulated potential of methane and electricity generation from sisal pulp, wastewater and sisal balls and the potential capacities in Tanzania for 2009 is presented in Table 4. The results for the best and a worst case scenario deviate strongly because of differing values reported in literature and known from practice. This illustrates the wide margin of possible fluctuations and the interrelated risks that need to be considered when running biogas plants with sisal residues as substrate. In light of these results the viability of initiatives proposed by the private sector (UNEP Risoe Centre, 2009) i.e., to generate 5-10MW electricity in the next five to ten years using only a small portion of the country-wide sisal residue potential, might need careful reconsideration. 
Table 4: Potential methane yield, electricity and heat production and installed capacity from sisal residues in Tanzania

\begin{tabular}{cccccc}
\hline & $\begin{array}{c}\text { Methane yield } \\
\text { [million } \\
\mathrm{m}^{3} / \text { year] }\end{array}$ & $\begin{array}{c}\text { Electricity } \\
\text { production } \\
{[\mathrm{GWh} / \text { year] }}\end{array}$ & $\begin{array}{c}\text { Heat generation } \\
{[\mathrm{GWh} / \text { year] }}\end{array}$ & $\begin{array}{c}\text { Installed } \\
\text { Capacity } \\
{\left[\mathrm{MW}_{\mathrm{el}}\right]}\end{array}$ \\
\hline \multirow{2}{*}{$\begin{array}{c}\text { sisal pulp \& } \\
\text { wastewater }\end{array}$} & $\begin{array}{c}\text { minimum } \\
\text { maximum }\end{array}$ & 8.5 & 25.5 & 32.3 & 3.6 \\
\cline { 2 - 6 } & average & 17.2 & 67.0 & 71.5 & 13.3 \\
\hline \multirow{2}{*}{ sisal balls } & minimum & - & 46.3 & 51.9 & 8.5 \\
& maximum & 9.8 & 29.5 & 37.3 & 4.2 \\
\cline { 2 - 6 } & average & 9.8 & 35.4 & 41.3 & 5.3 \\
\hline
\end{tabular}

\subsection{Current uses and availability of sisal residues}

In a country like Tanzania, where grass productivity is low and fertilizer costs are high, using crop residues as fodder or fertilizer has to be the priority and only surplus biomass ought to be converted into electricity. Sisal residues, however, are not yet utilized for any purpose in Tanzania, besides the small amount of residues used for electricity generation in the biogas pilot plant. The liquid nature of the residues has so far been regarded as a restriction for any other uses. But trials in Kenya showed that fresh sisal waste could possibly be fed to cattle as a supplement to natural pastures if the moisture content is reduced (UNIDO, 2005). If in the future sisal residues are to be used as animal fodder, the amount of residues available for sustainable electricity generation will be limited accordingly.

The actual available amount of sisal pulp and waste water depends on the fiber production levels, which touched bottom in Tanzania 2010. But with the economy recovering and the price for sisal fibers rising up to US\$1,050-1,200 per tonne between September and November 2010 (TSB, 2010), it is possible that production levels will rise again in the coming years. A production increase would result in a higher amount of available residues. In addition, the amount of fibers and therefore residues, could also be increased by improving the farming habits. On most estates so far neither fertilizer is used nor is land preparation done in order to improve yields and quality. Sisal yields on well-prepared land are about two tonnes per hectare per year in Tanzania compared to only one tonne per hectare per year on unprepared land. The use of organic fertilizer, that could for instance be obtained as by-product from the biogas production process (UNIDO, 2005), could further improve soil fertility and increase sisal yields. Applying these options to increase productivity would result in an excess amount of sisal pulp available for electricity generation. Sisal balls are currently not available as feedstock for energy generation. If this residue type should be utilized it implicates additional logistic efforts and expenses, as the balls are field residues and so far not collected but burnt or broken down and plowed under.

\subsection{Assessment of environmental risks and opportunities}

The use of agricultural residues for energy purposes has the advantage of avoiding direct land-use competition with existing land uses and greenhouse gas emissions from land-use changes. But emissions from current waste incineration and the amount of residues which could be sustainably removed from the fields remain a concern (WBGU, 2009; UNEP, 2009).

Greenhouse gas emissions. Sisal residues are currently not properly disposed in Tanzania, if waste disposal is defined as the management of waste for the duration of its biological and chemical activity to prevent negative effects on the environment. The mixture of sisal pulp and wastewater is left on the bare soil from where wastewater leaks out into the soil and close by water bodies. The residues decomposing in the open lead to the formation of methane $\left(\mathrm{CH}_{4}\right)$ that is released into the atmosphere. Because methane is 25 times more potent has a GHG than carbon dioxide $\left(\mathrm{CO}_{2}\right)$, it contributes heavily to global warming and the associated negative effects on our environment (IPCC, 2011). The estimated 505,440 tonnes of sisal pulp produced in 2009 generate methane emissions over the next ten years that are equivalent to 184,622 tonnes of $\mathrm{CO}_{2}$. By using anaerobic treatment inside a closed digester these emissions can be substantially reduced. This would significantly reduce lifecycle GHG emissions and contribute to climate change mitigation. 
Water use and water quality. Agriculture-based economies like Tanzania require large amounts of water for irrigation and crop processing. Up to $90 \%$ of the total water withdrawals in Tanzania are accounted for by the agriculture sector of which the largest amount is used for irrigation purposes (FAO AQUASTAT, 2010). Growing sisal however, does not require irrigation, as the sisal plant is drought resistant and cultivated as rain fed crop. But the processing of sisal leaves is very water intensive and on average $100 \mathrm{~m}^{3}$ of water are used to produce one tonne of fiber (GTZ, 2010). Reducing this amount of water would be beneficial in terms of environmental sustainability as well as in terms of energy generation. In particular in Tanzania where water is a scare resource, reducing the overall water use is an important requirement if the biomass production aims to be sustainable (RSB, 2010).

The utilization of sisal residues has the additional benefit that ground and surface water pollution is significantly reduced (CFC, 2004). Because at present water from the sisal production is simply drawn off to nearby water sources, being the main origin of water pollution in regions with high sisal production. Utilizing and treating sisal pulp and wastewater therewith directly benefits the environment and helps to fulfill the sustainability requirement that biomass production, should not lead to contamination of water sources (RSB, 2010).

Biodiversity. According to the RSB standards, biofuel operations shall avoid negative impacts on biodiversity, ecosystems, and other conservation values (RSB, 2010). Although the use of sisal residues has no direct effects on biodiversity, the cultivation of the sisal plant itself surely has.

The degree of biodiversity in agricultural ecosystems depends on the diversity of vegetation within and around the agro-ecosystem, permanence of crops and intensity of management (Southwood \& Way, 1970). With regard to these factors, agricultural monocultures are known to significantly reduce biodiversity by replacing nature's diversity with a small number of cultivated plants (Altieri \& Nicholls, 2004). Most common shortcomings arising from monoculture cultivations include displacement of natural vegetation, nutrient losses, intensive use of fertilizer and pesticides. Today, like most commercial crops in Africa, sisal is almost exclusively grown in monocultures. It dominates the scenery in the sisal growing regions in Tanzania. In Tanga, the main sisal growing region of Tanzania, 67\% of the cultivated land is planted with sisal (Table 5). But compared to other cash crops sisal is grown rather extensively than intensively. Despite the fact that neither chemical fertilizer is applied nor pesticides are used, due to the absence of plant diseases that would affect fiber production, monoculture cultivations of sisal significantly reduced the biodiversity in the sisal growing regions of Tanzania. Risks of additional biodiversity loss exist, if expansion and intensification are undertaken to generate additional residues for energy purposes. However, the use of currently generated residues does not implicate further biodiversity losses.

Table 5: Indicators for biodiversity in agricultural ecosystems

\begin{tabular}{|c|c|}
\hline Indicator & \\
\hline Agricultural area per crop [ha] & $188,131^{1}$ \\
\hline Average area per estate [ha] & $3484^{2}$ \\
\hline Number of plants per ha & $3,000-4,000$ \\
\hline $\begin{array}{l}\text { Land cultivated with sisal } \\
\text { [\% cultivated area] }\end{array}$ & $\begin{array}{r}\text { Total: } 3.7 \\
\text { (Regions: Tanga 67; } \\
\text { Morogoro 23; Kilimanjaro 6; } \\
\text { Mara 4) }\end{array}$ \\
\hline $\begin{array}{l}\text { Dominance of non- } \\
\text { domesticated species to } \\
\text { domesticated species }\end{array}$ & $\begin{array}{r}\text { High in Tanga and } \\
\text { Morogoro }\end{array}$ \\
\hline Use of agricultural pesticides & none \\
\hline Use of agricultural fertilizers & none \\
\hline
\end{tabular}

Soil health. Agricultural residues contain nutrients and maintain soil carbon content and fertility. They also provide protection against erosion and can contribute to soil biodiversity (UNEP, 2009). Therefore, environ- 
mentally sustainable biomass operations should implement practices that seek to maintain soil health and/or reverse soil degradation (RSB, 2010). In particular, it needs to be carefully observed to what extent residues can be removed and what quantities have to remain on the field in order to maintain the nutrient cycle.

As mentioned before sisal is mainly grown on monoculture plantations. These plantations often exist for decades, continuous cultivating sisal without adding fertilizer. Although no soil pollution is caused from chemical fertilizer, this cultivation practice also implies that the soil is impoverished. Moreover, almost no residues are left on the field to provide nutrients. The only residues that remain on the field after a lifecycle of about 10 years are the sisal balls and these are often also burnt on the field. Hartemink et al. (1996) and Hartemink (1997) studied the nutrient balance under monocropping sisal in the absence of fertilizers in Tanzania. He observed that both nutrient balance and soil nutrient contents showed a serious shortfall for each nutrient. The largest absolute decrease was found in the soil nitrogen content, resulting in decreasing yields per hectare. Using sisal residues to generate biogas could improve the nutrient regime, since the digestate from biogas generation can be used as organic fertilizer (Kaltschmitt et al. 2009). Trials on test fields in Tanzania have verified that using sisal digestate as fertilizer improves soil fertility and increases sisal yields. In practice the logistics of distributing the digestate to the fields still constitute an obstacle. Theoretically the utilization of sisal residues for energy generation can contribute to improving the environmental sustainability and economic performance of sisal production.

\subsection{Assessment of socio-economic risks and opportunities}

In producing and using bioenergy, a number of socio-economic factors need to be taken into account if the requirements for sustainable development are to be met (WBGU, 2009). These aspects need to be especially careful assessed in developing countries, where the agricultural sector plays a key role for economic and social progress. Although decentralized energy generation with agricultural residues has potential to provide the rural poor with multiple benefits, no guarantee exists that activities help to satisfy local development needs. The sustainable biomass principles therefore require that in regions of poverty, biofuel production shall contribute to social and economic development and ensure the human right to adequate food and livehood (RSB, 2010).

Improved access to basic services. Availability of clean and affordable energy is fundamental to reduce poverty and increase pro poor growth. Like in most developing countries, the rural population in Tanzania has very limited access to modern energy services. Hence, agricultural residues that are primarily available in rural areas are a potential feedstock for decentralized energy generation.

Compared to the processing of crops, like sugarcane with five processing sites or coffee with four major processing sites, sisal processing is more decentralized with 35 processing sites operating in Tanzania in 2010 (TSB, 2010). In theory the available electricity potential from sisal pulp and wastewater residues is sufficient for an installation of about $8.5 \mathrm{MW}$ capacity and can provide more than 40,000 rural households with electricity (estimating consumption to be $200 \mathrm{kWh}$ per person per year and six persons per household). But in practice it is not certain that access to electricity services will increase locally. Connecting the local population requires additional investments, because establishing mini-grids is cost intensive and collecting fees requires additional work efforts and increases costs. Even subsidies of US $\$ 500$ for each newly establishes electricity connection are offered by the Rural Energy Agency of Tanzania (established by the Rural Energy Act 2005) to make mini-grids more attractive for private sector investments, most investors hesitate to invest in rural electrification. Consequently most involved stakeholders expect the more likely scenario to be, that power is primarily used to run factories and surplus electricity is fed into the grid, as the majority of processing sites already have a connection to the national grid. This development will be further enhanced by the Standardized Small Power Purchase Agreements (SPPA) coming into place in 2008. The agreement offers small independent power producers standardized contracts and fixed prices for electricity sales to the national electric supply company TANESCO, making the administrative process of feeding electricity into the national grid more simple. But even if electricity generation from sisal residues will most likely not directly improve access to energy services; it can contribute to reducing the constant power shortfalls in the country.

Income generating opportunities. Bioenergy utilization is expected to benefit rural laborers by offering them employment in raising biomass or working at the bioenergy facility. However, the rural poor do not automatically benefit from these income opportunities. The question is, if the adoption of biogas technology in the sisal sector will result in additional local employment and capacity building. 
The sisal industry in Tanzania is dominated by large scale plantations with recent developments towards outgrower schemes ${ }^{3}$. The gross of the workforce in the sisal sector can therefore be divided in two groups: plantation workers and outgrowers. Workers employed on the plantation do not own any resources so they do not directly benefit from value adding activities like power generation from the residues. Outgrowers sell the entire sisal leaves to the processing companies so they do not have a stake in the major residue, the sisal pulp. Yet they do own the sisal ball residues, but presumably this residue type will not be utilized until a later stage of biogas developments. So the only potential benefit for smallholder outgrowers in the near future might come from higher sisal prices due to the fact that residues become a valuable energy source.

However, this development is uncertain, because poor rural farmers typically operate in a buyer's market with imperfect information. Awareness raising and information campaigns could help to enable outgrowers to participate in the benefits electricity generation with residues offers to the sisal sector.

Compared to the limited new income opportunities for the rural population in sisal harvesting and processing, direct and permanent employment potential exists at the biogas facilities. Utilizing the technical realizable electricity potential of sisal residues could create between 65 to 764 new jobs in the decentralized rural areas of Tanzania (assuming biogas plants with 500kW capacity; operating 7,000 hours per year; running each plant with three work shifts per day and 3-7 workers per shift). Table 6 presents an overview of the possibilities and limitations of employment in biogas generation with sisal residues for the rural population.

Table 6: Selected indicators for income generating opportunities in the context of biogas production with sisal residues in Tanzania

\begin{tabular}{|c|c|c|}
\hline \multicolumn{3}{|l|}{ Indicator $^{1}$} \\
\hline Jobs/€ million invested & $\begin{array}{l}\text { [Assumption: } 8.5 \mathrm{MW} \\
\text { capacity; investment per } \\
\mathrm{kW} € 2,500-4,000 ; 65- \\
764 \text { jobs created] }\end{array}$ & $2.4-27.8$ \\
\hline Jobs/ 1000ha & $\begin{array}{l}\text { [Assumption: } 188,131 \text { ha; } \\
65-764 \text { jobs created] }\end{array}$ & $0.35-4$ \\
\hline Seasonality & \multicolumn{2}{|l|}{ operation all year round } \\
\hline $\begin{array}{l}\text { Accessibility to local } \\
\text { laborers }\end{array}$ & \multicolumn{2}{|c|}{$\begin{array}{l}\text { mainly as unskilled labor, but technical } \\
\text { training opportunities possible }\end{array}$} \\
\hline $\begin{array}{l}\text { Development of markets } \\
\text { for local farm and non- } \\
\text { farm products }\end{array}$ & \multicolumn{2}{|c|}{ no, most parts of equipment will be imported } \\
\hline $\begin{array}{l}\text { Local recycling of } \\
\text { revenue (through wages, } \\
\text { local expenditures, taxes) }\end{array}$ & \multicolumn{2}{|l|}{ limited } \\
\hline
\end{tabular}

In addition, temporary employment opportunities will be created in the fields of planning, manufacturing and construction of biogas facilities. Parts of the potential jobs require skilled labor forces. The acute shortage of trained technical professionals in the country could therefore prove to be a barrier for biogas development. The lack of skilled labor also implies that components are most likely imported and foreign experts are employed, reducing the profits and the benefits for the local population. Being aware of this problem a training center for biogas and biomass has been established in cooperation with private and public partners from Tanzania and Germany. So far one course for stakeholders was conducted rather than actual education of technicians that would be able to run biogas plants.

Land use competition and food security. Biogas production based on agricultural residues like sisal has only small impact on domestic food availability and causes little competition with existing land uses. Energy pathways utilizing agricultural residues, including sisal residues, should therefore be given priority over food crop and energy crop cultivation for energy generation.

\footnotetext{
${ }^{3}$ This Outgrower schemes can be defined as contract faming with binding arrangements through which companies ensures their supply of agricultural products by individual or groups of farmers (Felgenhauer \& Wolter 2008).
} 
Risks of extensive expansion of sisal cultivation areas to use the residues for energy generation and, in turn, potential land-use competition, are limited. The land currently in use for sisal cultivation is only a fraction of that dedicated to growing sisal over the last decades. On many estates sufficient parts of this land lie fallow, so that sisal production could be expanded without negative effects on food security. Only a massive increase in production could lead to land-use competition, but so far there are no indications of such a development. Although it could be argued that the land currently used for cash crops like sisal should be converted into land for food production, but sisal grows on dry and by now infertile soils that are often unsuitable for other crops. Furthermore agriculture commodities like sisal are Tanzania's most important export products providing a major source of income for the country. So the replacement of sisal would not add to environmental or socioeconomic sustainability.

\subsection{Overview of selected sustainability aspects relevant for energy generation with sisal residues}

Table 7 summarizes environmental and socio-economic sustainability aspects examined in this study. It is shown that electricity generation with sisal residues can be sustainable, if the right actions are taken. Moreover, if sisal residues are utilized for energy purposes, sustainability can be improved by reducing multiple environmental problems caused by the current form of sisal production in Tanzania. Only biodiversity is unlikely to increase as long as sisal is grown in monocultures. But initiated developments towards small holder sisal farming might in the future increase the amount of sisal grown in intercropping systems.

Table 7: Overview of effects on environmental and socio-economic sustainability in Tanzania

\begin{tabular}{lllc}
\hline Sustainability criteria & $\begin{array}{l}\text { Sisal fiber } \\
\text { production }- \\
\text { growing and } \\
\text { processing }\end{array}$ & $\begin{array}{l}\text { Using sisal } \\
\text { residues for } \\
\text { energy } \\
\text { generation }\end{array}$ \\
\hline Environmental & $\begin{array}{l}\text { Greenhouse gas } \\
\text { emissions } \\
\text { Water use \& } \\
\text { water quality }\end{array}$ & -- & ++ \\
& $\begin{array}{l}\text { Biodiversity } \\
\text { Soil health }\end{array}$ & -- & + \\
\hline Socio-economic & $\begin{array}{l}\text { Improved access } \\
\text { to basic services } \\
\text { Income } \\
\text { generating } \\
\text { opportunities } \\
\text { Land use } \\
\text { competition \& } \\
\text { food security }\end{array}$ & & + -- \\
\hline
\end{tabular}

++ very positive; + positive; +/- can have positive or negative effects depending on implementation; negative; -- very negative.

\section{Recommendations}

From this analysis it is evident that agricultural residues like sisal waste should be acknowledged as part of an alternative bioenergy strategy in Tanzania. It is recommend that:

- Bioenergy policy priorities in Tanzania that currently primarily focus on energy crops should also recognize electricity and heat production from agricultural residues as sustainable, decentralized energy option.

- Further research on information, policy, financial and institutional barriers needs to be conducted. These factors are essential components on whether the demonstrated technical potential can be realized in practice or not. 
- To ensure social sustainability of cogeneration with sisal residues it is necessary to explore options to use excess energy locally, such has mini-grids and direct biogas supply for cooking to neighboring rural households.

\section{Discussion}

Generally, assessments of bioenergy potentials focus largely on environmental factors whereas social aspects are taken into account far less frequently. Within the environmental dimension, biodiversity and climate aspects are overrepresented while soil and water aspects are often omitted (Smeets et al., 2009). With respect to these observations this study tries to extend the scope to social aspects as well as to the effects on soil and water.

Compared to other residues like bagasse from sugarcane, the country specific potential of sisal residues as energy source has not been studied with regards to sustainability and availability. Both Kivaisi (1996), who determined the methane yield and electricity potential, and Salum (2008), who evaluated the Clean Development Mechanism (CDM) potential of energy generation using sisal residues on four estates, indicated that a sufficient potential exists. But questions remain regarding the amount of different residue types and the sustainability of their use. Hence, the scope of this study was to conduct an independent assessment of the potential of sisal residues for electricity generation in Tanzania and to emphasize the multiple factors that influence availability and sustainability. In particular, the theoretical, technical and exploitable energy potentials have been differentiated and it has been found that sufficient amounts of sisal residues exist to generate electricity and heat. Even if initially only the available processing residues of sisal are used, if the dry matter content remains low and if the production levels continue to be low, the potential is adequate to generate $3.6 \mathrm{MW}$ electricity per year. These results are similar to the outcome of a technical potential assessment in Kenya (GTZ, 2010).

Utilizing this potential implies environmental and socio-economic risks as well as opportunities. If the energy generation from sisal residues aims to be sustainable, these factors need to be taken into consideration. The assessment of selected criteria showed that the use of sisal residues for electricity generation would lead to numerous opportunities and an improvement of the current situation with environmental and socioeconomic risks being limited. The quantification of this sustainably available amount of residues for electricity generation and evaluating the economic sustainability go beyond the scope of this study. Because both aspects are strongly site specific and this study is limited to an overall assessment of the country specific potential, therefore it cannot reflect explicit local conditions. Further this study is limited to examining the biogas potential for anaerobic digestion of sisal residues as only substrate (mono-fermentation). Adding other substrates can improve biological and chemical conditions and lead to an increase of biogas yields and electricity output. Nevertheless, these results can serve as input for site specific sustainability assessments of locally available potential and help create awareness among potential investors and policy makers about the viability of biogas from sisal residues as a source for electricity generation.

\section{References}

Altieri, M. A. \& Nicholls C. I. (2004). Biodiversity and Pest Management in Agroecosystems. Binghamton, NY: Food Products Press.

CFC (2004). Product and market development of sisal and henequen. Kenya - Tanzania. January 1997 December 2005. Common Fund for Commodities. Vienna: United Nations Industrial Development Organization.

Dasappa, S. (2010). Potential of biomass energy for electricity generation in sub-Saharan Africa. Energy for Sustainable Development, (15) 3, pp. 203-213.

Domac, J. (2005). Socio-economic drivers in implementing bioenergy projects. Biomass and Bioenergy 28 (2005), 97-106.

FAO (2010). Bioenergy and food security. The BEFS analysis for Tanzania. Environment and natural resources management working paper 35. Rome: The Bioenergy and Food Security Project/ Food and Agriculture Organization of the United Nations

FAO (2009). FAO Fibres Statistical Bulletin 2009. Rome. Food and Agriculture Organization of the United Nations.

FAO \& AGAL (2005): Livestock sector brief. United republic of Tanzania. Rome: Food and Agriculture Organization of the United Nations \& Livestock Information, Sector Analysis and Policy Branch.

FAO AQUASTAT (2010): FAO's global information system on water and agriculture. Rome: Food and Agriculture Organization of the United Nations. Retrieved December 04, 2010, from: http://www.fao.org/nr/water/aquastat/main/index.stm. 
FAOSTAT (2010): Agriculture production. Rome: Food and Agriculture Organization of the United Nations. Retrieved December 04, 2010, from: http://faostat.fao.org/.

Felgenhauer, K. \& Wolter, D. (2008). Outgrower Schemes - Why Big Multinationals Link up with African Smallholders. Paris: OECD. Retrieved December 04, 2010, from: http://www.oecd.org/dataoecd/47/27/41302136.pdf.

GTZ - (2010): Agro-industrial biogas in Kenya. Potentials, estimates for tariffs, policy and business recommendations. Berlin: German Technical Cooperation.

GTZ (2005). Liquid biofuels for transportation in Tanzania. Potential and implications for sustainable agriculture and energy in the 21st century. Eschborn: German Technical Cooperation.

Hartemink, A. (1997). Input and output of major nutrients under monocropping sisal in Tanzania. Land degradation and development. 8, 305-310.

Hartemink, A.; Osborne, J. F.\& Kips, Ph. A.(1996). Soil fertility decline and fallow effects in ferralsols and acrisols of sisal plantations in Tanzania. Expl. Agriculture, 32, 173-184.

IEA (2008). World energy outlook 2009. Electricity access database (2008 data country-by-country). Paris: Organisation for Economic Co-operation and Development/ International Energy Agency.

IPCC, 2011. Climate Change 2007. The Physical Science Basis. The Working Group I contribution to the IPCC Fourth Assessment Report. Errata, updated 3 oct. 2011. Table 2.14 (Errata). Intergovernmental Panel on Climate Change.

Kaltschmitt, M.; Hartmann, H. \& Hofbauer, H. (2008). Energie aus Biomasse. Grundlagen, Techniken und Verfahren. Heidelber, London, New York: Springer.

Kivaisi, A. K. (1996). The potential of agro-industrial residues for production of biogas and electricity. Renewable Energy (1-4), 917-921.

Koopmans, A. \& Koppejan, J. (1998). Agricultural and foerest residues. Generation, utilization and availability. Kuala Lumpur, Malaysia: Paper presented at the Regional Consultation on Modern Applications of Biomass Energy, 6-10 January 1997.

Marrison, I. \& Larson, E. D. (1996). A preliminary estimate of the biomass energy production potential in Africa in 2025. Considering projected land needs for food production. Biomass and Bioenergy, 10, 337-351.

MEM (2010). Overview of energy sector 2010. Dar es salaam: Ministry of Energy and Minerals Tanzania.

Mshandete, A. M;. Kivaisi, A.; Rubindamayugi, M. \& Mattiasson, B. (2004). Anaerobic batch co-digestion of sisal pulp and fish wastes. Bioresource Technology 95, 1, 2004, 19-24.

Muthangya, M.; Manoni, A. \& Kivaisi, A. (2009). Two-stage fungal pre-treatment for improved biogas production from sisal leaf decortication residues. International Journal of molecular science. 10(11), 2009, $4805-4815$.

Rosillo-Calle, F. (2007): The Biomass Assessment Handbook. Bioenergy for a Sustainable Environment. London. Earthscan.

RSB (2010). Principles \& criteria for sustainable biofuel production. Lausanne: Roundtable on Sustainable Biofuels.

Salum, A. (2008): Analysis of possibility of CDM through biogas production and electricity generation from sisal waste in Tanzania. Master's thesis. Aalborg University, Denmark.

Smeets, E. M. W.; Faaij, A.; Dees, M.; Lemp, D.; Koch, B.; van Busselen, J.; Gunia, K.; Goltsev, V.; Lindner, M.; Fritz, S.; Böttcher, H.; Vesterinen, P.; Verijonen, K.; Berndes, G.; Wirsenius, S.; van den Berg, D.; Vis, M.; Rettenmaier, N.; Koeppen, S.; Geletukha, G.; Popovski, K.; Vasilevska, S.; Kunikowski, G.; Lakyda, P.; Zibtsev, S.; Kajba, D.; Segon, V.; Domac, J.; Schneider, U.;14, Ramos, C.; Eleftheriadis, I.; Christou, M.; Lehtonen, A.; Mustonen, J. \& Anttila, P. (2009): A review and harmonization of biomass resource assessments. Hamburg, Germany: Proceedings, 17th European Biomass Conference and Exhibition - From Research to Industry and Markets, 29 June - 3 July 2009.

Smeets, E. M. W; Faaij, A. P. C.; Lewandowski, I. M. \& Turkenburg, W. C. (2007). A bottom-up assessment and review of global bio-energy potentials to 2050. Progress in Energy and Combustion Science, 33, 56106.

Smeets, E. M. W. ; Faaij, A. P. C.; Lewandowski, I. M. \& Turkenburg, W. C. (2004) A quickscan of global bio-energy potentials to 2050. An analysis of the regional availability of biomass resources for export in relation to the underlying factors. Utrecht: Copernicus Institute - Department of Science, Technology and Society Utrecht University.

Southwood, R. E. \& Way, M. J. (1970). Ecological background to pest management. In: Rabb, R. C. \& Guthrie, F. E. (Eds.). Concepts of Pest Management. Raleigh, NC: North Carolina State University. 6-29.

Tanzania Agricultural Sample Census (2003). National Sample Census of Agriculture 2002/ 2003. Crop sector national report. Dar es Salaam: National Bureau of Statistics, Ministry of Agriculture and Food Security, 
Ministry of Water and Livestock Development, Ministry of Cooperatives and Marketing, Presidents Office, Regional Administration and Local Government, Ministry of Finance and Economic Affairs - Zanzibar.

TSB (2009). Statistics. Tanga: Tanzania Sisal Board. Retrieved December 04, 2010, from http://www.tsbtz.org/Statistics.html.

TSB (2010). Unpublished data. Tanga: Tanzania Sisal Board.

UNEP (2009). Towards sustainable production and use of resources - Assessing Biofuels. Nairobi: United Nations Environment Programme

UNEP - Risoe centre. (2009). CDM project portfolio - Tanzania. - United Nations Environment ProgrammeRisoe centre. Retrieved March 11, 2011 from http://cd4cdm.org/subSaharan\%20Africa/Tanzania/Portfolio/CDMprojectPortfolio_Tanzania.htm.

UNFCCC (2006): Methodological tool. Tool to determine methane emissions avoided from disposal of waste at a solid waste disposal site (Version 05). - United Nations Framework Convention on Climate Change. Retrieved December 04, 2010, from: http://cdm.unfccc.int/methodologies/PAmethodologies/tools/am-tool04-v5.pdf

UNIDO (2005). Electricity, Heat and Fertilizer from Sisal- Biogas and Waste. United Nations Industrial Development Organization. Vienne: Retrieved December 04, 2010, from http://www.unido.org/index.php?id=6464.

WBGU (2009). World in Transition - Future Bioenergy and Sustainable Land Use. - German Advisory Council on Global Change. London: Earthscan.

World Bank. (2010). Energy in Africa: Overview. Washington, DC: The World Bank Group. 